\title{
LA DIFICULTAD DE LLAMARSE "AUTORA": MARIANA ENRIQUEZ O LA ESCRITORA WEIRD ${ }^{1}$
}

\author{
POR \\ LORENA AMARO \\ Pontificia Universidad Católica de Chile
}

En un número de julio de 2017, la revista argentina Los inRockuptibles llevaba en su portada a la escritora Mariana Enriquez, con motivo de la aparición de su última novela, Este es el mar, una historia de estrellas del rock en clave fantástica, en que unas hadas/brujas intervienen para convertir a los cantantes en "leyendas", empujándolos a la muerte. La novela, publicada por la editorial Penguin Random House, vino precedida del éxito editorial de Las cosas que perdimos en el fuego en Anagrama, la famosa casa catalana. La pestaña biográfica de Este es el mar informa que el libro antes mencionado recibió el premio Ciutat de Barcelona y está siendo traducido ni más ni menos que a dieciocho idiomas. La publicación de Enriquez en España constituye, indudablemente, un hito importante en la internacionalización de su carrera, y la imagen de Enriquez en Los inRockuptibles le hace honor a este éxito literario. También, a la temática de su nueva novela: se la puede ver ligeramente de perfil, con lentes oscuros y vestida completamente de negro; los botones del abrigo están cerrados hasta el cuello y solo asoman parte de una mano y dos grandes anillos de plata, a punto de zambullirse en el bolsillo. La propia Enriquez bien podría ser, a juzgar por esta imagen y el título de la entrevista en las páginas interiores -"Estrella distante"-, una cantante de rock acosada por las hadas. La alusión a la siniestra novela de Roberto Bolaño pareciera reflejar, por otra parte, la consistente relación de Enriquez con el género del terror, rasgo ineludible de su imagen autorial. Una imagen con muchos vaivenes, que será abordada, a continuación, en este artículo.

Enriquez es autora de las novelas Bajar es lo peor (1995/2013), Cómo desaparecer completamente (2004), Este es el mar (2017) y de los libros de cuentos Los peligros de fumar en la cama (2009), Cuando hablábamos con los muertos (2013) y Las cosas que

\footnotetext{
Este artículo se inscribe en el proyecto "Carto(corpo)grafías del siglo XXI" (Fondecyt-Chile Regular 1180522) de la Comisión Nacional de Investigación Científica y Tecnológica (CONICYT) del Gobierno de Chile, del que soy la investigadora responsable.
} 
perdimos en el fuego (2016). Ha escrito también la nouvelle Chicos que vuelven (2010), las crónicas de Alguien camina sobre tu tumba. Mis viajes a cementerios (2013) y la biografía La hermana menor. Un retrato de Silvina Ocampo (2014); ha participado en volúmenes colectivos, como Los malditos (2011), de Leila Guerriero, en que aborda la vida de Alejandra Pizarnik (“Alejandra Pizarnik, vestida de cenizas") y escribe periódicamente columnas periodísticas para Página/12, donde también es subeditora del suplemento cultural Radar. Ha sido destacada principalmente como cuentista y suele figurar en los panoramas y cartografías de los escritores latinoamericanos contemporáneos suyos, nacidos entre 1970 y 1980, cuyas carreras se encuentran en plena consolidación. Si bien ha vivido distintos momentos de reconocimiento, como aquella portada consagratoria, la escritora, nacida en 1973 en Buenos Aires, suele posicionarse en sus entrevistas muy lejos del interés por la fama. Se podría aventurar, incluso, que, como muchas escritoras latinoamericanas, ha debido enfrentar los vaivenes del campo literario, todavía adversos a la autoría femenina. Ser "autora" sigue siendo aun hoy, en el siglo XXI, un camino de difícil recorrido para quienes lo emprenden. Las escritoras suelen ser abordadas como un "caso aparte", un fenómeno editorial; los comentarios sexistas abundan en las páginas culturales de los periódicos. Esta marginación alcanza también al ámbito académico, donde suelen ser discriminadas en el discurso crítico. Por solo citar un ejemplo vinculado con el propósito de este artículo, en 2009 Julio Premat publica el ensayo Héroes sin atributos. Figuras de autor en la literatura argentina, donde dedica sendos ensayos a Macedonio Fernández, Jorge Luis Borges, Antonio Di Benedetto, Osvaldo Lamborghini, Juan José Saer, Ricardo Piglia y César Aira, para establecer distintas figuras de autor argentinas. No incluye a ninguna autora y explica en la "Introducción":

El autor es un concepto diacrónico y relacional: autores son los otros, los que preceden la propia creación, ante los cuales el texto que surge se sitúa. Escribir es enfrentar al padre, es marcar la hoja con una marca transgresiva. Es inscribir, por lo tanto, al personaje que se crea en el juego de las influencias, de las filiaciones, de las rebeliones edípicas, de los parricidios y las expiaciones -en todo caso, así es para los escritores hombres estudiados aquí-. (27)

La aclaración ("hombres") pareciera apuntar a la conciencia del crítico sobre la exclusión que está operando en su texto. Por otra parte, podría desprenderse de este párrafo que es el autor varón, fundamentalmente, quien se construye, como indica Premat, en una "red relacional". No dice nada sobre las mujeres, aunque es patente que intuye diferencias. Las críticas Aina Pérez Fontdevila, Meri Torras Francés y Elena Cróquer proponen un análisis que explica este tipo de omisiones y exclusiones. En la introducción de un reciente dossier titulado "Género y autoría" (2015), y a partir del análisis de Nathalie Heinich del denominado "régimen de singularidad" de la autoría en

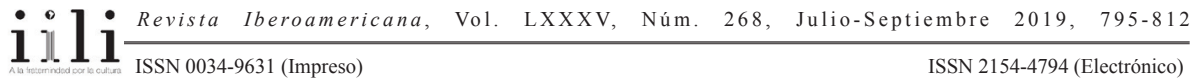


Occidente -que hace de la misma algo excepcional, fuera de lo habitual, irrepetible-, observan cómo las escritoras han sido excluidas de ese paradigma de la construcción autoral, fundada en la oposición a lo común y lo comunitario (espacio en que se sitúa habitualmente la producción cultural femenina):

el artista devendrá una figura-espejo de la supuesta singularidad irreductible o irrepetibilidad de cada ser humano, situándose entre dos posibles paradigmas: el del sujeto (o Autor) construido a imagen y semejanza del Dios cristiano, cuya creación se asemejará a la creación divina en tanto que responderá a la ficción de la creación ex nihilo; y el del sujeto inspirado, que producirá obras originales en virtud de su relación con una fuente exterior suprahumana $[\ldots](19-20)$

En el otro extremo de la balanza se situará la producción femenina, la cual nunca es desvinculada de su relación con lo corporal y lo colectivo, estableciendo de este modo formas específicas de autoría que no compiten con las de los autores varones:

De este modo, pues, las exclusiones en que se fundamentan las posiciones-artista deslegitiman como productores de arte a todos aquellos sujetos que no son conceptualizados como corporal o culturalmente transparentes, es decir, que no pueden acceder al estatuto de "autor de la obra", representante de su "poder singular", porque su ligazón al cuerpo o a la colectividad los sitúa del lado de la (re)producción material o simbólica: el suyo será el ámbito del producto manufacturado, de la transmisión folclórica, de la repetición tradicional del artesanato; o, en otro orden de cosas, será el ámbito de la confesión, el testimonio, el ejemplo o el portavoz. Pero no el ejemplo de la idiosincrasia de lo humano (la irrepetible individualidad) o el portavoz de una instancia singularizadora que se manifiesta en soledad, sino el portavoz del colectivo al que pertenece, de sus inscripciones corporales o culturales, que es incapaz de trascender $[\ldots](22)$

No es extraño, entonces, que un libro como el de Premat, dedicado a la construcción autoral en la literatura argentina, desdeñe a las importantes autoras del siglo XX. La mujer aparece desprovista de "soberanía" (Pérez, Torras y Cróquer 20), la que se construye por su soledad, propiedad y control hermenéutico de la propia obra: "Su vinculación al cuerpo también la condena en otro sentido: en tanto que sujeta a sus particularidades, lo que ella produzca no alcanzará la universalidad que se atribuye también a la verdadera obra de arte" (21). A esto habría que añadir otro punto, que Premat deja insinuado en su texto: si la construcción de la autoría se produce en una "red relacional", la producción femenina halla la doble dificultad de remontar no solo el desdén hacia una subjetividad supuesta y exclusivamente afincada en su biología y la indistinción de su sexo, sino que además es difícilmente ubicable en términos de la construcción del campo literario. Si la autoría masculina se produce en el constante

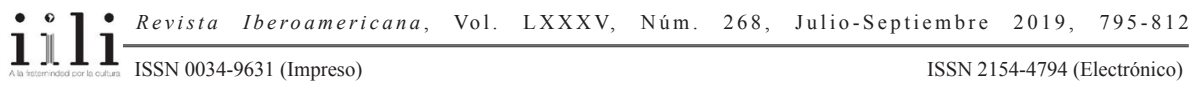


enfrentamiento con el padre y en el quehacer edípico que cierra e inaugura modos discursivos tensionados por el edipismo de la "angustia de las influencias", ¿qué ocurre con la construcción de la autoría femenina en lo que respecta a sus relaciones y redes, su rechazo o adhesión a lo que llamamos la "tradición"?

La autoría femenina debe confrontarse, entonces, con ese doble desafío: 1) remontar el rechazo de lo colectivo y lo corporal, diseñar estrategias que tampoco tienen por qué volver a la autoría/origen cuestionada por la postmodernidad; 2) conseguir inscribirse en un diálogo literario con el pasado y el presente, algo que las propias escritoras han transformado en su tarea cuando construyen sus genealogías literarias, a veces verdaderas arqueologías en que logran sacar a la superficie textualidades enterradas e ignoradas.

He planteado anteriormente que autoras como Mariana Enriquez aún enfrentan -y sobre todo hoy- la escritura discriminadora de la crítica y la prensa cultural, que encasilla la producción femenina -por lo general con significativos comentarios sobre su corporalidad, su belleza, sus modos de vestir o sus poses-, generando imágenes de ellas que perpetúan su inclusión en una suerte de ghetto cultural. ${ }^{2}$ En el caso particular de Enriquez, desde luego que hay una serie de estereotipos que la escritora ha debido enfrentar y superar para poder construirse como autora y resistir las lecturas e imágenes reduccionistas, que por supuesto pueden marcar la lectura de su producción literaria.

Para abordar la construcción de su "figura autorial", definida esta como un "producto en sí mismo textual (es decir, como un corpus conformado por un conjunto de textos heterogéneos: biográficos, académicos, visuales, autográficos, etc.)" (Pérez Fontdevila y Torras 2), se utilizarán conceptos provenientes de los llamados "Estudios Autoriales", los que consideran al autor "más allá de su realidad fáctica, como sujeto real, para retomarlo como producto textual e histórico" (3), una figura caleidoscópica particularmente en este siglo XXI, en que tantos textos e imágenes circulan virtual y mediáticamente. Se trabajará con el concepto de "imagen de autor", delineado por Dominique Maingueneau (2015), figura inestable que emerge de la "interacción entre participantes heterogéneos", lectores, público y otros agentes del campo literario que producen este verdadero "artefacto" (véase Cróquer) de la autoría. Maingueneau procura superar, con ese concepto, los análisis que distinguen o separan tajantemente el texto de su contexto biográfico, o lo que se ha distinguido como un "ethos discursivo" focalizado en la enunciación del escritor, y la "postura", que privilegiaría sus estrategias como

\footnotetext{
2 Reportajes culturales recientes muestran hasta qué punto las mujeres siguen siendo desplazadas en los discursos en torno al mainstream literario. Así, por ejemplo, en un texto de 2012, Maximiliano Tomás, periodista, columnista y editor de la antología La joven guardia. Nueva narrativa argentina, publicada en la Argentina en 2005, y en Cuba y España (2007 y 2009, respectivamente), habla solo de cuatro autoras en un largo listado de escritores recientes, en un texto publicado en La Nación, "Algunos nuevos escritores argentinos que usted no conoce (y debería conocer)": Mariana Enriquez, Samanta Schweblin, Natalia Moret y Selva Almada.
}

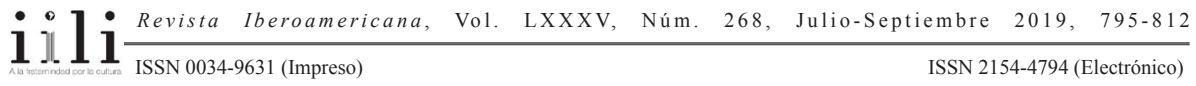


productor para posicionarse en el campo literario. El concepto de "imagen de autor", sin embargo, debe enfrentar las dificultades que entraña la definición de la propia "autoría". Maingueneau define, en efecto, dos “zonas de activación”, estrechamente ligadas: la que concierne al texto y la que concierne al actor literario. Este último, explica, se libra en un doble trabajo de "configuración" y "figuración":

La "configuración" está orientada hacia el ajuste de la obra; pasa por varios géneros: manifiestos, debates, escritos sobre otras artes, prefacios a obras de otros escritores, obras sobre otros escritores... Permite reorientar la trayectoria en la cual se inscribe cada obra singular: ser escritor es también gestionar la memoria interna de sus textos y de sus actividades anteriores, y reorientarlas en función de un porvenir. A este trabajo de "configuración" se mezcla el trabajo de "figuración" a través del cual el actor, en cierto modo, se pone en escena como escritor: viaja o no, vive retirado en el campo o en el centro de una gran ciudad, sale en televisión o esconde su cara, concede entrevistas a la prensa escrita, etc. (21)

Con estas formas de "configuración” y “figuración” por supuesto se entremezcla el discurso de los otros: las palabras de todos aquellos quienes contribuyen a modelar la imagen del autor. En el caso de Mariana Enriquez, la “configuración” está dada por una gran cantidad de textos en prensa que abordan cuestiones artísticas, principalmente los breves ensayos que escribe para Página/12, reflexiones en que aborda series televisivas, cómics, música e incluso las circunstancias en que escribió algún texto suyo (por ejemplo, la columna a pedido "El cuento por su autor", en que relata cómo escribió "El mirador", incluido en Los peligros de fumar en la cama ${ }^{3}$ ). No hay manifiestos ni poéticas explícitas en Enriquez, pero sí sus declaraciones en entrevistas y las alusiones que hace a su propia escritura en pasajes de sus narraciones; en este sentido, abordaré principalmente su "Nota a la edición" en Bajar es lo peor, donde, a 18 años de haber publicado esta, su primera novela, se refiere a lo que fue la escritura y recepción de la misma. También resultan particularmente significativos dos de sus libros, aquellos en que se aleja de la ficción para incursionar en géneros "referenciales", como la crónica de viajes, en Alguien camina sobre tu tumba, y la biografía literaria, en La hermana menor, donde escribe un extenso perfil de Silvina Ocampo. El texto, editado por Leila Guerriero, surge poco después de que Enriquez escribiera sobre Alejandra Pizarnik para la conocida recopilación Los malditos, compilada también por la famosa cronista argentina. Pero mientras a Pizarnik le destina un perfil algo distante, muy bien escrito pero descomprometido, en el caso de Silvina - cuentista de filiación fantástica, como Enriquez-, las adjetivaciones de la narradora, sus pensamientos y lecturas de la obra

Se trata de una sección estandarizada de este periódico, que publica los cuentos comentados y que se diferencia por ello de otros textos publicados por la autora en ese medio.

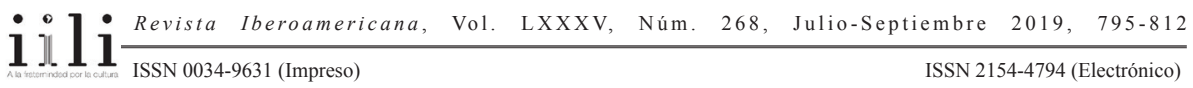


ocampiana constituyen de algún modo un espejo de su propia "configuración" autorial. No en vano, desde hace algunos siglos la biografía literaria funciona como una suerte de espejo entre el biografiado y su biógrafo (véase Dosse). Es así como en este último texto, Enriquez delinea una suerte de genealogía que anuda su quehacer como escritora del género fantástico y de terror con el de la autora de Autobiografía de Irene; esta genealogía dice relación con su construcción como "autora" en lo que Premat llamaba una "red relacional".

\section{"LA ESCRITORA MÁs JOVEn DE ARgentina"}

Enriquez entremezcla en sus obras elementos del terror gótico, lo fantástico, la cultura del cómic, el cine y una escritura política que se interroga por la violencia en Argentina, ya sea a través de los cuentos en que aborda cuestiones como el feminicidio, la droga o la violencia urbana, o esboza, en cuentos de envoltorio weird ${ }^{4}$ las huellas de la dictadura en la cotidianidad de su país. Sin embargo, este registro múltiple, postmoderno, apenas deja lugar a la creación autobiográfica. A diferencia de muchos otros autores de su generación en Argentina y Latinoamérica, su obra narrativa rehúye las autoficciones, por lo que la imagen autorial de Enriquez se alimenta, principalmente, de paratextos como las entrevistas, y de rápidas pero significativas alusiones en los libros antes señalados, sus crónicas sobre cementerios y la biografía de Ocampo. Sin embargo, su primera "imagen de autora" está lejos de todas estas cuestiones, y seguramente constituye un hito que debió ser difícil de remontar para una autora inteligente como Enriquez.

Ya se ha dicho que ella comenzó a publicar muy joven. Su primera novela, Bajar es lo peor, se publicó en 1995, cuando tenía apenas 21 años. Su novela era, también, juvenil: drogas, noche, alcohol. Protagonistas que no tienen una identidad sexual fija. Delirios, alucinaciones. No es raro que se convirtiera en un texto emblemático de una juventud descarriada. Tal vez tampoco es raro que por su edad y por el carácter contracultural y de culto del texto, se la encasillara, a Enriquez, como una autora "juvenil", primera imagen que impactará sobre su inserción en el campo literario por varios años.

Nora Domínguez ha advertido sobre estas autorías femeninas traspasadas por el discurso falocéntrico, en que las escritoras figuran como "objeto de mirada y modelo de belleza" (14). La juventud, en el caso de las mujeres, es un atributo por lo general asociado a su apariencia; en el caso de Enriquez, la fama de su primera novela -que le atrae a verdaderos fans enamorado/as del magnético protagonista, el romántico

\footnotetext{
4 Bajo este calificativo, que podría traducirse como "bizarro" o "extraño", se describen textos fundamentalmente narrativos que entremezclan el horror, la ciencia ficción y lo fantástico, una literatura que surge a fines del siglo XIX con autores como Edgar Allan Poe o H. P Lovecraft.
}

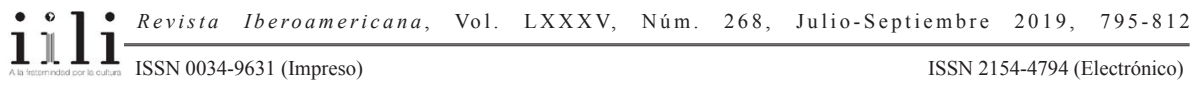


Narval- la lleva por los medios de comunicación como una portavoz femenina del mundo juvenil.

La propia Enriquez escribe, dieciocho años después, en su nota a la segunda edición de Bajar es lo peor, lo que fue para ella cargar con el estereotipo de los medios: "Ir a la tele a hablar con Chiche Gelblung y aparecer en talk shows hablando de por qué los jóvenes son violentos (ésa era la consigna de la tarde); que me presentaran a escritores que yo no conocía y jamás había leído; que en la radio el libro se promocionara con la frase "la escritora más joven de Argentina"' (9). En este texto, de 2013, escribe que no ha querido leer esta novela nuevamente, para no intervenirla, porque le "gusta" (10). La propia escritora alimentó, a través de sus entrevistas, los rasgos de culto de la novela, remarcando en sus conversaciones con los medios su cercanía con la cultura pop y algunos subgéneros literarios, incluso en conversaciones más cercanas en el tiempo. Así, por ejemplo, en esta entrevista concedida en 2014 a Flor Codagnone, la escritora se recuerda a sí misma joven, ingenua, sin saber bien lo que estaba haciendo, también algo indefensa, razón por la que se entregaba a los dictámenes de periodistas y entrevistadores.

Me parece que todo texto, lo quiera o no, habla de su época. Probablemente Bajar es lo peor hable de los 90 . Yo, sin embargo, no tenía ninguna intención sociológica. A esa edad no se me podía ocurrir. Eran mis experiencias, mis obsesiones, mis vicios, mi callejeada. Yo pienso poco en los lectores, pero supongo que está bueno que se sepa que es una primera novela. Me parece que gran parte de su encanto, si es que tiene uno, es ése: ser una primera novela, sin mediaciones literarias, una novela que escribió alguien que no sabía nada.

-iY, cómo fue recibida entonces?

-Me acuerdo de que era: “¿Las drogas!” “iLos gays!”. Me preguntaban “¿Te drogas?” y era extraño. Pensaba que si les decía que sí iba en cana. ¿Cómo me iban a preguntar eso? Hoy es distinto. No existe ese miedo ni esa posibilidad... Ahora quizá se le puede prestar más atención a lo fantástico. En ese momento nadie lo vio. Para todos era una novela realista tipo Menos que cero. Para mí, no, pero en ese momento era chica y decía que sí.

-Es extraño que se leyera de ese modo porque el elemento fantástico de la novela es muy fuerte.

-Creo que en algún momento la pensé como una novela de vampiros. Tiene algo de eso. En aquella época leía Entrevista con el vampiro, de Anne Rice. Hay una suerte de una referencia a Hellraiser y a The Sandman. Facundo, el protagonista, no es de verdad. Lo fantástico aparece del mismo modo que en Cumbres borrascosas: no sabés muy bien qué es Heathcliff, no es muy "persona", es como un demonio... (Codagnone, párr. 5-9)

Es interesante la breve polémica que menciona, cuando plantea que a su alrededor comentan la relación de la novela con el realismo y el universo de la Generación X

$111 \frac{\text { Revista Iberoamericana, Vol. LXXXV, Núm. 268, Julio-Septiembre 2019, }}{1195-812}$ 
(la alusión a Menos que cero, la también primera novela de Bret Easton Ellis). Si bien Enriquez sabía cuáles eran sus referentes literarios (Cumbres borrascosas, Entrevista con el vampiro, el cómic The Sandman, el filme Hellraiser), adopta un rol pasivo frente a los medios: "En ese momento era chica y decía que sí".

Pasaron nueve años antes de que Enriquez publicara su segunda novela, en 2004, un tiempo en que estudió en la universidad y comenzó a trabajar como periodista. Cómo desaparecer completamente se ambienta en una villa miseria y aborda nuevamente la experiencia de la juventud, esta vez en la figura de Matías Kovac, protagonista que deambula por la ciudad buscando salir de la cárcel siniestra en que se ha convertido su casa. Cuenta para sobrevivir con un cuaderno de anotaciones que ha dejado su hermano mayor, que ha logrado escapar de esta realidad entremezclada con las drogas, la violencia y el rock. Se ha calificado esta novela, por estos y otros elementos, como un "Bildungsroman pop". La temática juvenil no desaparece: el mismo título es un intertexto de la cultura popular musical, ya que "How to Disappear Completely" es el título de una canción de Radiohead. Si bien esta novela incorporaba más elementos de crítica social, no tuvo la recepción de su predecesora.

\section{Autoría WEIRD DE UNA LITERATURA WEIRD}

Ya con treinta años Enriquez logra atravesar los límites con que socialmente se margina no solo a la mujer, sino también a la juventud en tanto "subcultura"; se libera del estereotipo de jovencita fiestera con que la coronaron los periodistas culturales de los noventa, para ir elaborando la figura autorial que es hoy, en que dos aspectos parecen fundamentales: por una parte, su filiación a géneros marginales, no reconocidos académicamente, $y$ a tradiciones literarias de culto, alejadas de los lineamientos centrales del canon, como la novela de terror, el "fantasy", la narrativa weird, géneros en los que si bien históricamente las autoras han tenido un importante impacto (desde Mary Shelley a Anne Rice), son minoritarias. Enriquez aparece, entonces, en sus entrevistas como una "rara", una escritora ecléctica que recoge una diversidad de registros y voces en sus textos, con un fuerte influjo de la cultura de terror y ficción anglosajona, que suma a la rareza de ser mujer en un espacio consagratorio masculino, el ser latinoamericana y plantear en sus textos una mirada política de una sociedad enfrentada a grandes desigualdades y violencias. En esta línea fue decisiva la publicación de los cuentos de Los peligros de fumar en la cama (2009), en que aborda estas cuestiones con relatos muy bien trabajados, que buscan provocar miedo en sus lectores. Sin embargo, se trata de un libro de ficción; cuanto sugiera o permita entrever de las inclinaciones de su autora, se puede contrastar mejor con las entrevistas en que Enriquez refuerza esta imagen de autora de literatura fantástica.

Por estos años, otro gesto importante en su "figuración" como escritora fue la aparición, en 2013, de las crónicas Alguien camina sobre tu tumba. Mis viajes a

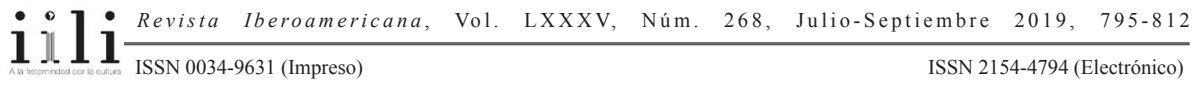


cementerios, donde recoge crónicas escritas en distintos momentos y delinea claramente su preferencia morbosa por la muerte, el vampirismo, el vudú, la rareza, todos ellos temas que aparecen en estos textos. En varias de estas crónicas literarias, el personaje "Mariana Enriquez" ocupa un lugar central. El texto que encabeza el libro, "La muerte y la doncella", es decisivo porque marca la lectura de los restantes: aparece una Mariana Enriquez joven, noventera, que descubre lo que será su pasión por los cementerios. Obsesiva, ha delineado un itinerario por Europa que contempla la Venecia de Byron y un paso "obligado" por Bomarzo ("necesitaba ver el Parque de los Monstruos que Mujica Láinez había usado para escribir su novela [...]" [12]). Como viajera, Enriquez es ante todo una lectora que va en busca de esas lecturas. Pero se cruza en su camino la posibilidad de conocer el cementerio de Staglieno, en Génova: "No estaba entre las paradas obsesivas que había planeado. Sabía, sí, que existía. Sabía que una de sus espectaculares tumbas había sido la tapa del disco Closer y otra, la del single Love will tear us apart, ambos de Joy Division, pero nunca me gustó Joy Division [...]”. Las referencias culturales con que se acerca a la necrópolis, como se puede ver, pertenecen al mundo pop de sus dos primeras novelas y de muchas de sus columnas, pero aquí se va perfilando una identidad nueva: "Entonces no era catadora de cementerios, como ahora [...]". En Génova, Enriquez conoce a un joven violinista italiano, con el que vivirá una aventura erótica en el cementerio: "Enzo era la criatura más hermosa que yo había visto [...] para mí, para mi idea de belleza, que es turbia y pálida y elástica, oscura y azul, un poco moribunda, pero alegre, más atardecer que noche [...]. Un inglés italiano, pensé, una criatura de Mary Shelley y Byron [...]" (13-14). Recuerda su beso: "Estaba frío por debajo de la camisa fina. Frío y pálido. Como un vampiro, como una estatua. Como el chico más lindo del mundo" (15). Son constantes las alusiones a la necrofilia contenida en las eróticas sepulturas de este cementerio, en que la propia Mariana aparece como un personaje romántico: "Recuerdo los dedos de Enzo enredados en los breteles de mi vestido negro [...]" (18), un vestido negro juvenil, ceñido, corto, con zapatillas, que por otro lado da cuenta de aquella escritora joven, de culto, que fue Enriquez en ese tiempo. En palabras de su enamorado, ella es "la bruja que no me deja dormir y me hace caminar por cementerios sexys" (20). Nada como este primer encuentro iniciático y sexual, que no tendrá parangón en otras crónicas donde hallamos otras autofiguraciones de Enriquez, ya con otras luces: "Yo, ridícula, con altos borceguíes, una pollera negra y una remera colorada, punk rocker vieja a la media tarde, devorada por un perro" ("Los perros negros" 50); "Nos sentamos frente a un grupo de mujeres empitucadas que no parecen comprender cómo hay que vestirse para una excursión y nos miran con curiosidad y reproche: estamos despeinados, de negro, yo sin maquillaje"; "Un laberinto cerca de un hotel me hace recordar la película El resplandor. No digo nada. ¿Si la que se vuelve loca por el encierro en la isla, esta noche, sin luz, soy yo?” ("Acá nadie se muere" 54 y 56-7); "Cuestionan mi locura funeraria. No les hago caso porque estoy acostumbrada a la censura" ("Un dominicano sin cabeza” 72). "Quise

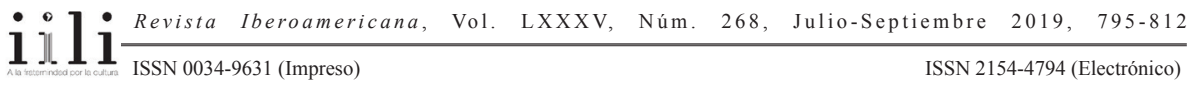


alojarme ahí, a pasos de la calle Prytania. Un homenaje narcisista a mi adolescencia y mis fantasías. Nueva Orleans también es una ciudad de vampiros [...]" ("Ciudades de los muertos" 135). Los guardas de los cementerios le preguntan a la narradora si le gustan las "historias truculentas" (86) y con frecuencia ella plantea la posibilidad de volverse loca frente a alguna bella estatua funeraria, configurando así una nítida imagen de sus "parafilias" y una genealogía literaria y cultural romántica y tenebrosa.

En este libro sobre sus viajes a cementerios Enriquez incursiona en el mundo de los muertos, en las necrópolis que si bien se han ido integrando al mercado del turismo y sus recorridos espectacularizados, conforman ese revés de lo vivo, de lo deseable y de lo sano, que la autora se apropia en esta y sus ficciones por venir. Su gesto de transitar por esos lugares otros, deviene en rareza: la narradora nos confronta permanente a lo que es usual, a lo común, mostrándonos de ese modo la excepcionalidad de su conducta: "Los argentinos, sean isleños, pampeanos, mesopotámicos o patagónicos, tienen un problema con el tema de los fantasmas. No le ven atractivo, no le ven potencial pintoresco; no sé si les tienen miedo a las ánimas o tienen miedo de perder plata o son insólitamente poco morbosos" (“Acá nadie se muere" 55).

Los argentinos son "ellos", los otros. No Mariana Enriquez, instalada en el polo opuesto y desmintiendo con su conducta errática y rebelde los recorridos turísticos tradicionales (que suele quebrantar). Enriquez es la "rara". Una rareza personal que contamina su literatura, produciendo una interesante figura. Eleonora Cróquer define la autoría "rara" como un "artefacto cultural" (214), una "superficie privilegiada para leer lo que una cultura (concebida en términos de 'comunidad') imagina como su "diferencia"" (214). Esta "rareza" es constitutiva del canon: conforma su contracara, la posibilidad de los escritores de construir, a partir de este elemento, sus propias genealogías, como lo hicieran Rubén Darío con una modernidad literaria rebelde, "maldita", inclasificable (desde la europea Rachilde al americanista Martí) o, más recientemente, Pere Gimferrer. Y menciono el establecimiento de genealogías porque más allá de figurarse como "rara" (necrófila, oscura, morbosa), Enriquez delinea a través de su literatura y sus intervenciones en prensa, un universo literario propio, en que autores como Ray Bradbury, Stephen King y Neil Gaiman ocupan lugares poco frecuentados en los mapeos habituales de los escritores latinoamericanos. Enriquez opta por visibilizar, como hicieran antes Borges o Bolaño, a escritores usualmente fuera del canon (y cantantes de rock desaparecidos, y escritores amputados, entre los muchos fetiches mencionados por la autora). La opción de Enriquez es queer (la sexualidad, como en algunos de sus cuentos, adquiere ribetes inimaginados) y es weird. Ella lo reivindica así, por ejemplo en esta entrevista de Flavio Lo Presti sobre el terror:

Es sencillamente mi género favorito de siempre, desde que leí Otra vuelta de tuerca de Henry James o a Stephen King de chica. Creo que es un género popular-eso me gusta, me importa- que, a la vez, ofrece una inmensa libertad porque abarca virtualmente

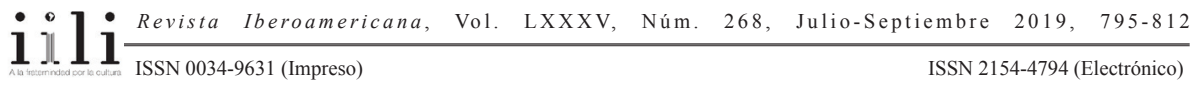


todo: el horror es una emoción, de modo que un cuento de horror puede tener policial, realismo, ciencia ficción, procedimientos más experimentales, y más. Que esté bastante al margen también me atrae, que se lo considere "menor" hace que escribir en el marco del género de terror sea un poco secreto y esa situación relativamente oscura determina que se puedan encontrar en el género textos muy estimulantes: no estar en el centro te libera de ciertas miradas "importantes" y otras pomposidades. Yo los llamo cuentos "extraños": los escritores anglosajones últimamente los llaman "new weird" y me parece una definición más amplia y más adecuada. Por otra parte, no tengo demasiada relación con escritores del género en castellano. Hay cada vez más, pero como no formo parte de ningún grupo o lo que sea, también estoy fuera de las internas (si las hay, que desconozco, pero sospecho que sí, como en todas partes). (Lo Presti, párr. 4)

Es por decir lo menos interesante que una escritora que vivió el éxito y una rápida incorporación al mercado literario en su juventud, declare su atracción por la literatura "minoritaria", "al margen", "secreta", gesto que combina perfectamente con la identidad alternativa forjada en las crónicas. Fundamental resulta la libertad que permite este lugar en términos creativos; es quizás esa libertad la que le permite conjugar sus lecturas weird, sobre todo anglófonas, como ella misma plantea, con una inquietud fundamental de la literatura latinoamericana, desde sus orígenes: la relación con lo político y el correlato nacional. Así lo plantea en las siguientes entrevistas:

"El terror siempre es político", apunta la narradora argentina. O por lo menos lo es "en un país que creó fantasmas como política de Estado", dice en referencia a la espectral figura jurídica del desaparecido bajo la que se esfumaron 30.000 almas desde el golpe de la Junta Militar de 1976 hasta la apertura democrática de 1984. (Néspolo, párr. 2)

La literatura con un fuerte compromiso político no me cautiva: la respeto y la entiendo, pero no me representa [...] La literatura de género también puede ser política, como Drácula, que puede ser leída como un comentario acerca de la aristocracia, por ejemplo. Decir que la literatura de género no es política es una tontería, un comentario que atrasa [...] Te doy otro ejemplo: una de las mejores críticas acerca de la Inglaterra del thatcherismo es el Hellblazer de Jamie Delano, mucho más que la literatura de Ian McEwan. John Constantine, el personaje principal, incluso, en un número es puesto cabeza abajo por unos demonios para que vea por la televisión la elección de Thatcher, ¿qué mejor comentario político que ése? (Bogado, párr. 2)

Chicos que vuelven, la potente nouvelle de Enriquez sobre unos niños que estaban desaparecidos y regresan prácticamente intactos a Buenos Aires, representa este interés de la escritora por conjugar mundos de horror fantástico con la historia argentina de los últimos años. Los chicos desaparecidos no están involucrados en política; el contexto en que se han perdido no es el de la dictadura argentina. Sin embargo, la reflexión que suscita esta historia nos conduce a pensar qué es lo que pasó con aquellos que 
volvieron del horror y cómo una sociedad puede reconstruirse, cómo se puede volver a ser comunidad, cuando buscan reincorporarse los cuerpos marcados de quienes experimentaron en carne propia el horror. Otros de sus cuentos, como "Cuando hablábamos con los muertos", abordan el período dictatorial de manera directa, siempre en la huella de interrogar aquella biopolítica que creó la figura del "desaparecido" para inscribirlo en una suerte de limbo entre lo vivo y lo muerto, intersticio que la literatura del terror suele poner en evidencia. ${ }^{5}$

\section{LA ESCRITORA SECRETA}

En su último libro de cuentos, Las cosas que perdimos en el fuego, la mayoría de los textos se define por la estética del miedo y el terror; tampoco falta en ellos la crítica social. Enriquez abre el volumen con el relato "El chico sucio", emplazado en un barrio venido a menos de la ciudad de Buenos Aires, el barrio de Constitución, en el que lo interesante no es que ella vuelva la mirada hacia los sectores más vulnerables, como algunos han remarcado -niños de la calle, adolescentes en riesgo social, mujeres víctimas de la violencia machista-, sino que coloque lo siniestro, lo que produce el miedo, en zonas fronterizas, de contacto entre un mundo y otro. Tanto la narradora de ese como las de otros cuentos, se encuentran del lado de la cotidianidad y la cordura, y no del otro, donde abundan la violencia y la irracionalidad. En "El chico sucio", se trata de una mujer de clase media que opta por volver al caserón familiar semiabandonado; en el lovecraftiano "Bajo el agua negra", la protagonista, Mariana Pinat, es una fiscal que decide ingresar sola en los peligrosos territorios de Villa Moreno, sin que nadie la obligue a ello. Son mujeres que bien podrían funcionar como correlatos literarios de la autora, formas de alter ego, tanto por su condición social como por el control que sostienen sobre los universos que exploran. El terror y el miedo se entremezclan asimismo con otros malestares, como la culpa que siente una asistente social, despedida con razón de su último trabajo, en "El patio del vecino", o la angustia al ver que un amigo se encuentra encerrado al borde de un abismo virtual, sin contacto con la realidad y en las fronteras aparentemente sin retorno de la deep web, en "Verde rojo anaranjado". El miedo emerge, pues, en el espacio de la comodidad. Lo siniestro se activa cuando los y las protagonistas de estos relatos se dan cuenta de su lugar de frontera, reconociendo al otro, viéndolo y observándose a sí mismos al borde de una

5 En este cuento, los desaparecidos son invocados por un grupo de jovencitas a través de la tabla ouija. El desaparecido adquiere la forma del fantasma, también del zombie. Leila Guerriero cita estas palabras de una entrevista previa de Enriquez: "Siempre me gustó escribir terror, y es lo que más me gusta leer. El problema es que es muy fácil caer en el cliché. Y el otro problema es quedarte sin tema: ¿cuántas veces podés escribir sobre el fantasma, sobre el muerto vivo?" (párr. 9). La cuestión del "fantasma", como la del "zombie", aparece con toda su ambigüedad afectiva en distintos relatos y entrevistas de la autora. 
racionalidad distinta, de otra dimensión. El miedo radica en el hecho de mirar hacia el jardín vecino y darte cuenta de que un día puedes quedar atrapado allí, en un mundo aparentemente cercano, pero totalmente desconocido y aterrador.

Es así como surge otro rasgo también muy importante en la autoría weird de Enriquez, quien escribe su literatura desde una posición femenina y feminista: su crítica de la violencia machista, particularmente en un cuento que asemeja rasgos de la literatura anticipatoria, "Las cosas que perdimos en el fuego" (incluido en el libro homónimo y también en Cuando hablábamos con los muertos), un relato sobre el feminicidio, en que las mujeres, en respuesta a las vejaciones sufridas de manos de hombres, deciden quemar sus rostros y cuerpos, subvirtiendo la imagen de la víctima sacrificada por su pareja. En el cuento las activistas hablan de una "nueva belleza" de las mujeres, quienes habrán de caminar con sus cuerpos y rostros desfigurados por las calles, enrostrándole a la sociedad esta violencia. "Silvina", la protagonista, colabora con la causa, pero no ha tomado la decisión de inmolarse en el rito que se ha vuelto masivo. El horror, entonces, radica tanto en la inminencia del propio acto sacrificial, como en el feminicidio como gesto naturalizado por una sociedad indolente. La inversión practicada por Enriquez es igualmente violenta, pero como ocurre también en otros de sus relatos protagonizados por mujeres, que son numerosos, abre claros sobre la relación de ellas con su entorno social, las constricciones que moldean sus cuerpos y los desgarros que sufren diariamente. Enriquez pareciera apelar asimismo a una genealogía narrativa, cuando llama a su protagonista "Silvina": como la Ocampo, escritora sobre la que escribe una importante biografía. Con ese nombre inserta este cuento en una genealogía de lo fantástico, en que las heroínas de Silvina Ocampo, como otras protagonistas literarias de mitad del siglo XX, se vieron inmersas tempranamente en atmósferas enrarecidas, que amordazaban y violentaban sus cuerpos. ${ }^{6}$

Esa genealogía, insinuada en el cuento, es robustecida por el extenso perfil que le destina Enriquez a Silvina en La hermana menor, un retrato de Silvina Ocampo, donde cuenta la vida de la gran cuentista, además de novelista, poeta y pintora, usualmente opacada por las eminentes figuras que habitaron su entorno. Una idea que, por cierto, Enriquez critica:

El más común de los lugares comunes sobre Silvina Ocampo es considerar que quedó a la sombra, oscurecida, empequeñecida por su hermana Victoria, su marido el escritor Adolfo Bioy Casares y el mejor amigo de su marido, Jorge Luis Borges. Que la opacaron. Pero es posible que la posición de Silvina haya sido más compleja. Quienes la admiran fervorosamente decretan sin duda que fue ella quien eligió ese segundo plano. Dicen que desde allí podía controlar mejor aquello que deseaba controlar. Que nunca le interesó la vida pública, sino, más bien, tener una vida privada y libre y lo

6 Por citar un solo ejemplo: La casa del ángel, de Beatriz Guido, de 1954.

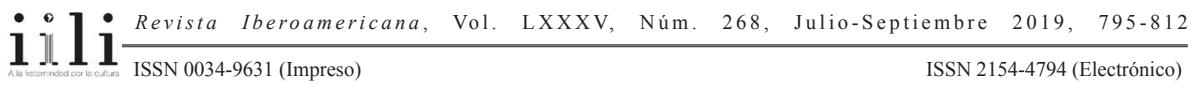


menos escrutada posible. Que, en definitiva, ella inventó su misterio para no tener que dar explicaciones. (La hermana menor 46)

A lo largo de su texto, Enriquez procura dejar abiertas las interpretaciones sobre la enigmática escritora. "Silvina es secreta" (11), argumenta desde la primera página. Y procura liberarla de posibles encasillamientos, sobre todo de la idea de víctima que pudiera rondar algunos textos en torno a la autora. Para Enriquez, Silvina parece ser una escritora con suficiente agencia para trazar los términos de la vida que ella, una aristócrata argentina, deseaba vivir. Si bien la experiencia de Enriquez dista más de 60 años de la de Ocampo (además de haber entre ambas otras muchas palpables diferencias $^{7}$ ), es posible percibir en este trabajo de rescate cierta admiración por el personaje, sobre todo por su originalidad y misterio, su peculiar forma de "rareza". Sin pretender resolver lo que hay detrás de las máscaras y los gestos escurridizos de Ocampo, Enriquez recoge las diversas fuentes existentes, de quienes la conocieron o escribieron sobre ella, además de leer sus grandes creaciones, como los cuentos de Viaje olvidado, Autobiografía de Irene y Cornelia frente al espejo y esa extraña autobiografía que es Invenciones del recuerdo. Construye así el retrato de la dama rica que vivió de una manera extrañamente precaria en lo material, pero mucho más allá de eso, la de una heroína que, lejos del realismo, por un lado, y de la perfección formal de la narrativa borgeana (aunque a veces, también, muy cerca), se empeñó en crear mundos autónomos, libres, descabellados. Inquietantes, como resulta ser la poética de la propia Enriquez. Así, por ejemplo, caracteriza los textos ocampianos, una descripción que, por lo que ya se ha visto antes sobre la obra de Enriquez, se acerca en muchos puntos al universo narrativo de esta última narradora:

Gran parte de la literatura de Silvina Ocampo parece contenida ahí: en la infancia, en las dependencias de servicio. De ahí parecen venir sus cuentos protagonizados por niños crueles, niños asesinos, niños asesinados, niños suicidas, niños abusados, niños pirómanos, niños perversos, niños que no quieren crecer, niños que nacen viejos, niñas brujas, niñas videntes; sus cuentos protagonizados por peluqueras, por costureras, por institutrices, por adivinas, por jorobados, por perros embalsamados, por planchadoras. (17)

\footnotetext{
Hay muchos elementos en la construcción mitográfica de Ocampo que distan de ser asimilables a una escritora contemporánea como Enriquez. Si bien me ha parecido importante recalcar sus semejanzas estéticas -por su vocación cuentística, por la impronta de lo fantástico, lo bizarro y lo popular- es evidente que en la construcción biográfica de estas autoras hay cuestiones que las separan: desde el origen aristocrático de Ocampo (Enriquez viene de una familia de profesionales de clase media), pasando por todo lo alusivo al mito sexual de Silvina: su ambivalencia, su posible lesbianismo. Un biografema ausente de la construcción que la propia Enriquez ha delineado sobre sí misma, y en que la presencia de su esposo, el australiano Paul Harper, a quien dedica Alguien camina sobre tu tumba y compañero de viaje en varias de esas crónicas, aparece más como un signo normalizador que centrífugo.
}

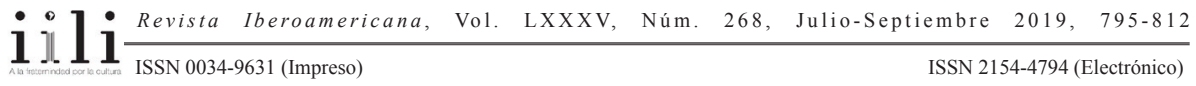


El énfasis de la cita anterior está puesto sin lugar a duda en la extrañeza y lo monstruoso, rasgos fundamentales en la estética de Enriquez. Por otra parte, en prácticamente todas las historias que ella cuenta sobre Silvina, deja entrever su extravagancia como mujer, como aristócrata, como escritora; la biógrafa revela mitos y los deja en suspenso, sin totalizar, sin cerrar la vida de su biografiada. El relato de Enriquez es como una compleja red de esclusas: abre una, la cierra, pasa a la siguiente, rehuyendo la dotación de un sentido único, y permitiéndole a su biografiada ser lo que quizás deseó ser: la escritora polimorfa que ante las cámaras fotográficas se tapaba el rostro (¿iracunda, seductora?). Logra configurar así una identidad huidiza, quebrada, inagotable. Con una vida y una obra que la hicieron extraña en su tiempo, de ahí su magnetismo y extraña contemporaneidad, que Enriquez recupera en lo que debiera pensarse como una biografía feminista, porque hace ver el lugar de una precursora y procura entrar en diálogo con ella.

\section{BORRARSE}

Hacia el final de su biografía sobre Silvina Ocampo, Enriquez recuerda como "estremecedora" la frase con que la Ocampo cierra su último libro, Cornelia frente al espejo: "Quisiera escribir un libro sobre nada" (cit. en Enriquez, La hermana menor 204). Leo esta frase -y la impresión que produce en Enriquez-a la luz de la propuesta crítica de Premat, quien propone la existencia de dos tendencias en sus lecturas sobre la construcción de la autoría en Argentina: "por un lado, la tendencia de los escritores a representarse dentro de una tradición renovada, pero reconocible, de la melancolía occidental. Por otro, la fuerte dimensión negativa de esta representación del sujeto que escribe; en la versión saeriana, una versión que se refiere [...] a Gombrowicz: 'El escritor no es nada, nadie"' (14).

Premat refiere tanto a una figura de autor como a un "personaje de autor", el escritor en las ficciones, cuya oscilación entre ser un "gran escritor" y no ser nada constituye un oxímoron reconocible de la literatura argentina del siglo XX. Esa tentación de la nada parece estar presente, asimismo, en las figuraciones de Enriquez, una autora que después de un gran éxito como Bajar es lo peor, escribe una novela titulada Cómo desaparecer completamente, en que el hermano del protagonista, autor de un cuaderno abandonado que sirve al protagonista como mapa de ruta, es la única prefiguración del escritor: un escritor desaparecido. En la última de sus ficciones, Enriquez aborda -aparentemente- la figura contraria, la de la estrella de rock, cuya rutina, sin embargo, conduce la huida del sujeto a su afantasmamiento. Sobre esta última novela ha escrito Beatriz Sarlo:

[Enriquez] convirtió en ficción algunos rasgos que el ensayista Omar Calabrese consideró signos de la postmodernidad. En primer lugar, la repetición como punto de

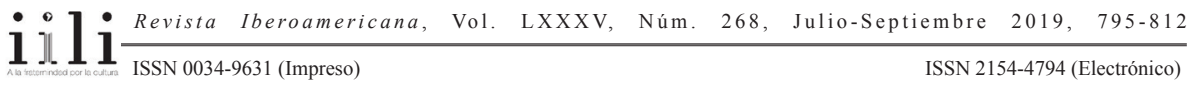


encuentro entre el artista y su público, que pide lo que ya ha escuchado del ídolo, porque la innovación no confirma el contrato original entre la estrella y sus fans que llegan hasta el recital para revivir lo conocido [...] todo cambio debe abstenerse de provocar una ruptura, un salto en la continuidad, una fisura entre los fans, sus expectativas y la música (párr. 11-12)

No sería extraño preguntarse por qué Enriquez escribe sobre la fascinación de estos ídolos musicales, y si en su libro no quiere decirnos algo también sobre el escritor consagrado, como insinué al comienzo de este artículo a propósito de la foto de Enriquez en Los InRockuptibles. ¿Cuánto hay de repetición y cuánto de originalidad en cada texto que engrosa lo que llamamos "la obra" de un escritor? ¿Cuánto tedio hay en los rituales específicos del campo, como los lanzamientos y firmas de libros en ferias y festivales? ¿Hasta qué punto el ritual renovado del mercado literario anula al "autor”?

En este artículo he recorrido distintas "configuraciones" y "figuraciones" de una autoría en constante crecimiento y cambio, desde la imagen de una autoría juvenil (en que el valor literario era supeditado por la prensa al morbo), a la consolidación de un espacio como autora weird, que es weird incluso bajo los parámetros que definen esta condición del escritor postmoderno: a la mixtura de géneros y códigos propia de esta literatura, Mariana Enriquez suma ciertos rasgos de ajenidad, como mujer escritora latinoamericana, que no ha entrado, según ella misma dice en sus entrevistas, en ninguna "red" de escritores de este tipo en Latinoamérica. La opción de Enriquez por lo marginal, lo camuflado, lo lateral y el desvío constituye la óptica, incluso se podría decir que la herramienta, de su interesante creación autoral, en la que también es posible percibir la tentación por la negatividad que a juicio de Julio Premat constituye una línea posible en la tradición de las imágenes autorales argentinas. Algo que Mariana Enriquez crea, al igual que su genealogía literaria, en que figuras como Silvina Ocampo son fundamentales, a despecho de una autoría femenina que aun hoy, incluso desde la crítica, parece difícilmente describible y abordable, pero que es preciso comenzar a visibilizar, sobre todo en un momento de gran efervescencia de la narrativa latinoamericana de mujeres, con importantes nombres y estéticas que reclaman la atención de los lectores. 
BiBLIOGRAFÍA

Bogado, Fernando. "Mi mundo privado". Radar. 5 ene. 2014. $<$ https://pagina12.com. ar/diario/suplementos/libros/10-5210-2014-01-11.html>. 24 oct. 2017.

Caamaño, Martín. "Estrella distante. Entrevista a Mariana Enriquez". Los InRockuptibles n. 226 (2017): 20-24.

Codagnone, Flor. "Cierta sed de belleza". Revista Ñ, Clarín. 28 abr. 2014. <https:// clarin.com/literatura/mariana-enriquez-cierta-belleza_0_ByfGhTcP71.html>. 24 oct. 2014.

Cróquer, Eleonora. "Ese entrañable objeto del deseo social o lo que algunos de nuestros casos de 'autor' (de)muestran". Estudios 21: 42 (2013): 203-237.

Domínguez, Nora. "Firmas de autora: autorrepresentación y distancia estética en la obra de Nicola Constantino". Estudios 21: 42 (2013): 109-121.

Dosse, François. La apuesta biográfica. Valencia: Publicaciones de la Universidad de Valencia, 2007.

Enriquez, Mariana. "Alejandra Pizarnik, vestida de cenizas". Ed. Leila Guerriero. Los malditos. Santiago de Chile: Ediciones Universidad Diego Portales, 2011. Alguien camina sobre tu tumba. Buenos Aires: Galerna, 2013.

Bajar es lo peor. Buenos Aires: Galerna, [1995] 2013.

"El cuento por su autor". Página/12. 3 febr. 2017. <https://pagina12.com. ar/17867-el-cuento-por-su-autor>. 24 oct. 2017.

La hermana menor. Un retrato de Silvina Ocampo. Santiago de Chile: Ediciones Universidad Diego Portales, 2014.

Guerriero, Leila. "No quiero que me saquen las pesadillas". El País. 3 may. 2016. $<$ https://elpais.com/cultura/2016/04/27/babelia/1461752532_057036.html>. 24 oct. 2017.

Lo Presti, Flavio. "Temor y temblor, los nuevos cuentos de Mariana Enríquez". La Voz. 12 may. 2016. $<$ http://lavoz.com.ar/ciudad-equis/temor-y-temblor-los-nuevoscuentos-de-mariana-enriquez>. 24 oct. 2017.

Mangueneau, Dominique. "Escritor e imagen de autor". Tropelías. Revista de teoría de la literatura y literatura comparada, 24 (2015): 17-30.

Néspolo, Matías. "El terror siempre es político". El Mundo. 8 feb. 2017. <http:// elmundo.es/cataluna/2017/02/08/589b76ffca47413c2c8b462d.html>. 24 oct. 2017.

Pérez Fontdevila,Aina; Meri Torras Francés y Elena Cróquer. "Amanera de presentación. Ninguna voz es transparente. Autorías de mujeres para un corpus visibilizador". Mundo nuevo. Revista de estudios latinoamericanos. Dossier "Autoría y Género", año VII, n. 16 (2015): 15-27.

Premat, Julio. Héroes sin atributos. Figuras de autor en la literatura argentina. Buenos Aires: FCE, 2009.

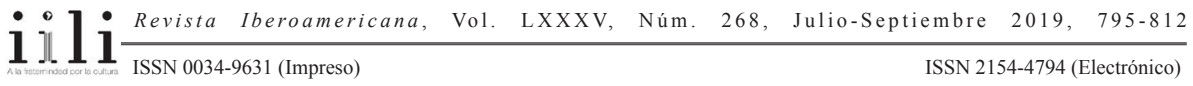


Sarlo, Beatriz. "El libro de la semana, por Beatriz Sarlo: Éste es el mar, de Mariana Enriquez". Cultura Télam.2 jun. 2017.<http://telam.com.ar/notas/201706/191112libro-semana-beatriz-sarlo-mariana-enrriquez.html>. 24 oct. 2017.

Tomás, Maximiliano. "Algunos nuevos escritores argentinos que usted no conoce (y debería conocer)". La Nación. 25 oct. 2012. <http://lanacion.com.ar/1520295algunos-nuevos-escritores-argentinos-que-usted-no-conoce-y-deberia-conocer>. 24 oct. 2017.

Torres, Alexander. "Cómo desaparecer completamente: un Bildungsroman pop. Resistencias implícitas en la cultura de masas". Revista intersticios de la política y la cultura. Intervenciones latinoamericanas. Universidad de Córdoba, 4 (2013): 87-107. <https://revistas.unc.edu.ar/index.php/intersticios/article/ download/5868/7385>. 24 oct. 2017.

Palabras clave: autoría, imagen de autor, new weird, violencia

Recibido: diciembre 2017

Aprobado: diciembre 2018 